\title{
TRANSFUSI DARAH DALAM TIMBANGAN FIKIH: Antara Najis dan Maslahah Perspektif Kaidah al-Ḍarar Yuzāl
}

\author{
Heny Lutfiana Hamdi \\ Universitas Islam Negeri Sunan Ampel Surabaya \\ E-mail: henylutfianahamdi96@gmail.com \\ Achmad Fageh \\ Universitas Islam Negeri Sunan Ampel Surabaya \\ E-mail: achmadfageh@gmail.com
}

\begin{abstract}
Abstrak: Transfusi darah termasuk permasalahan baru dalam wacana hukum Islam. Dalam konteks kajian Fiqh, darah termasuk benda najis secara dzatnya (lidzatihi). Dan tidak adanya hukum syar'i yang secara eksplisit membahas praktik transfusi darah. Hal ini menimbulkan kerancuan dalam kehidupan muslim. Risiko dan juga manfaat yang ditimbulkan dari praktik transfusi darah baik, dari pihak pendonor maupun penerima donor darah (resipien) perlu dipertimbangkan oleh keduanya. Tujuan dilakukanya ini adalah untuk menyelamatkan nyawa resipien baik, karena kecelakaan atau penyakit. Status hukum haram penggunaan darah menjadi wajib ketika dihadapkan dengan kebutuhan yang mendesak, pada saat transfusi darah menjadi satu-satunya jalan untuk menyelamatkan nyawa seseorang. Dalam hal ini didasarkan pada kaidah fiqhiyah asasiyah yang keempat yaitu: al-Darar Yuzāl (الضَّرَرُ يُزَالَ) bahwa bahaya itu harus dihilangkan/dicegah. Jadi praktik donor darah merupakan hal yang harus dilakukan untuk menghindari kemudaratan yang lebih besar, misal akan kehilangan nyawa apabila tidak segera melakukan donor darah. Di samping itu juga diungkapkan dalam sebuah hadis yang diriwayatkan oleh Ibnu Majah dari Ibnu Abbas, لَا ضَرَرَ وَلَا ضِرَرَ (tidak boleh memudaratkan dan tidak boleh dimudaratkan). Maka dari itu, dalam praktiknya transfusi darah perlu dipatuhi prosedur persyaratan dari program kesehatan kepada pihak pendonor dan resipien agar supaya tidak hanya menghilangkan bahaya resipien tapi juga terhindar dari membahayakan pihak pendonor.
\end{abstract}

Kata kunci: Hukum, Transfusi Darah, Kaidah al-Ḍarar Yuzāl

\begin{abstract}
Blood transfusions are a new problem in Islamic law discourse. In the context of Jurisprudence studies, blood includes unclean objects material (lidzatihi). And there is no syar'i law that explicitly addresses the practice of blood transfusions. This confuses Muslim life. Risks and also benefits arising from the practice of blood transfusions both, from donors and recipients of blood donations (recipient) need to be considered by both. The purpose of this is to save the lives of the recipient either, because of accidents or diseases. The unlawful legal status of the use of blood becomes mandatory when faced with urgent needs, at a time when blood transfusions are the only way to save a person's life. In this case, it is based on the fourth principle Fiqhiyyah rule which is: al-Darar Yuzāl (الضَّرَرُ يُزَالَ that the danger must be eliminated/prevented. So the practice of blood donation is a thing that must be done to avoid greater harm, for example, it will lose lives if it
\end{abstract}


does not immediately make a blood donation. Also, it is revealed in a hadith narrated by Ibn Majah from Ibn 'Abbas, لََ ضَرَرَ وَلَ ضِرَر (not to fade and should not be harmed). Therefore, in practice, blood transfusions need to have adhered to the procedural requirements of the health program to donors and recipients so as not only to eliminate the danger of recipients but also avoid harm to the donor.

Keyword: Law, Blood Transfusion, Rules of al-Darar Yuzaāl

\section{Pendahuluan}

Salah satu permasalahan baru dalam wacana hukum Islam tentang transfusi darah. Karena secara faktual status hukum praktik transfusi darah dalam konteks kajian fikih tidak terungkap secara eksplisit pada waktu penyusunan aturan hukum Islam. Bahkan dalam alQuran maupun al-Hadits sebagai sumber dasar hukum Islam tidak menjelaskan hukum tersebut secara komprehensif. Sehingga permasalahan ini disebut sebagai masalah ijtihadilah maka proses penyelesaiannya pun menggunakan jalan ijtihad oleh para ulama.

Al-Quran hanya mengisyaratkan tentang status darah sebagai barang yang najis dimana pemanfaatannya dilarang dipergunakan. Hal ini diungkap secara jelas dalam al-Quran

"Diharamkan bagimu (mempergunakan) bangkai, darah, daging babi, dengan hewan yang disembelih bukan atas nama Allah".

Selain itu juga berdasarkan sabda Rasulullah SAW dikatakan, "segala jenis darah adalah najis, terhitung juga darahnya manusia (HR. Bukhari dan Muslim)”, oleh karena itu, dalam aturan Islam dilarang digunakan secara langsung maupun tidak langsung dalam hal apa pun, Tubuh adalah amanat dari Allah SWT dan manusia tidak memiliki hak terhadap badannya untuk merusak, memotong, atau menduplikasikannya untuk orang lain. ${ }^{2}$

Kaitannya pada praktik transfusi darah tidak dapat dipungkiri bahwa risiko yang akan muncul akibat dilakukannya donor darah yaitu menimbulkan bahaya (mudarat) bagi diri pihak pendonor maupun pihak penerima donor (resipien). Meskipun melakukan transfusi darah dapat menolong nyawa orang lain dari bahaya kematian akibat suatu penyakit atau kecelakaan. Akan tetapi juga rentan terhadap terjadinya bahaya berupa komplikasi serta konsekuensi dari aktivitas menransfusikan darah seperti alergi, hemolytic dan meriang, cedera paru-paru akut (TRALI/Transfusion Related Acute Lung Injury), Hemokromatosis, Graft Versus Host Disease, bahkan infeksi. ${ }^{3}$

Oleh karena itu, dari latar belakang masalah diatas maka perlu dikaji secara mendalam mengenai hukum dilakukannya praktik transfusi darah oleh pihak pendonor kepada penerima donor darah (resipien) dengan menggunakan teknik analisis kaidah Fidhiyah asasiyah yang ke-4 (empat) yaitu kaidah al-Ḍarar Yuzāl (الضَّرَرُ يُزَالُُ). Oleh karena itu berdasarkan hal tersebut maka fokus kajian ini akan difokuskan pada analisa Hukum Transfusi Darah berdasarkan kaidah al-Darar Yuzāl.

\footnotetext{
${ }^{1}$ QS. Al-Maidah (5): 3.

${ }^{2}$ Hendi Suhendi, Fiqh muamalah (Jakarta: Rajawali Pers, 2014), 72.

Reni Utari, "Risiko Komplikasi dan Efek Samping Transfusi Darah", SehatQ, KEMENKES RI, https://www.sehatq.com/artikel/cenderung-jarang-terjadi-simak-komplikasi-dan-efek-samping-transfusi-darah-ini, diakses pada 09 September 2020, 1.
} 


\section{Kaidah al-Darar Yuzāl : Tinjauan Etimologis dan Dasar Hukumnya 1. Pengertian kaidah al-Darar Yuzāl}

Artinya: "Kemudaratan harus dihilangkan".

Segala sesuatu yang dapat mendatangkan kemaslahatan dengan membawa manfaat dan juga dapat menolak kemafsadatan yang mengakibatkan mudarat atau setidaknya dapat meringankannya, hal itu merupakan tujuan dari syariah (Maqāṣid al-Shari'ah). Seperti contoh orang yang sakit memiliki kewajiban untuk berobat bukan membiarkannya saja, sehingga dapat menyebabkan kehilangan nyawanya. Hal dengan peristiwa tersebut wajib dihindari. Oleh karena itu segala jenis kemudaratan itu harus dihindari. ${ }^{4}$

Secara etimologi lafad Mudarat berasal dari beberapa kalimat yaitu: ${ }^{5}$

a. الضَّرَرْرُ memiliki arti turun dan tiada yang bisa mencegahnya.

b. الضَّرَرُ dikatakan mutlak dapat membahayakan orang lain.

c. Al-Dhirar (الضرَرَرُر) yaitu dapat memudaratkan yang lain dengan jalan yang bukan syariah.

Terdapat beberapa lafaz yang berakar dari lafaz ضرر yang terkandung dalam kitab suci, yaitu al-Quran. Dan pada lafaz ayat tersebut menyuruh agar selalu berusaha melakukan kebaikan dan melarang tindakan yang dapat merugikan; misal kewajiban untuk mengikuti ajakan memperbaiki hubungan (إصلح) suami istri, hal ini kaitannya dengan QS. al-Baqarah ayat 228. Contoh lainnya yaitu tidak boleh merujuk istri dikarenakan maksud yang tidak baik (ضرار), hal ini kaitannya dengan QS. al-Baqarah ayat 231. Dan juga dalam hal pembagian warisan dilarang membuat keputusan yang dapat merugikan (مضـار غير), dalam hal ini dapat dilihat pada Al-Quran Surah al-Nisa (4): 12. Dan juga pada Surah al-Baqarah (2): 233 dikatakan bahwa dilarang membuat rugi sesama anggota keluarga antara suami, istri dan juga anak (لاتضـار) dan juga menyusahkan istri dalam hal ini terdapat pada al-Quran Surah al-An'am (6): $6 .{ }^{6}$

Berdasarkan pada terminologi dikatakan bahwa al-Dararu menurut pendapat mereka yaitu: ${ }^{7}$

a. Menurut Abu Bakar al-Jashas, Darar ialah suatu hal yang ditakutkan terjadinya sesuatu hal yang dapat membahayakan nyawa atau pada bagian tubuhnya.

b. Al-Dariri berpendapat bahwa Darar merupakan bentuk penyelamatan dari ancaman kematian atau dari hal-hal yang dapat menyulitkan diri.

c. Pendapat dari sebagian Ulama Mazhab Maliki mengatakan bahwa yang termasuk Darar ialah termasuk kekhawatiran diri dari kematian baik itu sudah yakin atau hanya dugaan saja.

d. Imam al-Suyuti berpendapat bahwa Darar diumpamakan dengan situasi seseorang ketika berada pada suatu batasan, lalu jika enggan mengonsumsinya meski hal itu dilarang maka dapat dipastikan ia akan binasa.

\footnotetext{
${ }^{4}$ Ahmad Abd. Madjid, Ushul Fiqh (Pasuruan: Garoeda Buana Indah, 1991), 90.

${ }^{5}$ Fathurrahman Azhari, Qawaid Fiqhiyyah Muamalah (Banjarmasin: Lembaga Pemberdayaan Kualitas Ummat (LPKU), 2015), 101.

${ }^{6}$ Fathurrahman Azhari, Qawaid Fiqhiyyah Muamalah (Banjarmasin: Lembaga Pemberdayaan Kualitas Ummat (LPKU), 2015), 01.

${ }^{7}$ Ibid., 102.
} 
e. Dikatakan Dirar merupakan suatu hal yang dapat memberikan keuntungan pada dirinya namun dapat memberikan kerugian (mudarat) pada lainnya. Selain itu, Darar merupakan sebaliknya, yaitu tidak menguntungkan (mudarat) kepada dirinya diri namun menguntungkan pada lainnya. Pendapat ini merupakan pendapat al-Nadwi yang mengutip pendapatnya al-Khusni.

Oleh karena itu dapat disimpulkan dari beberapa pernyataan ulama diatas yaitu Darar merupakan tingkat kesulitan yang dapat menentukan eksistensi manusia, apabila dibiarkan maka dapat membahayakan bagi jiwanya, agamanya, keturunannya, hartanya maupun kehormatannya maka diwajibkan menghindari atau menolaknya. Sebagaimana dikatakan bahwa Darar merupakan bentuk bahaya yang mesti dihindari dan ditolak.

\section{Sumber Hukum kaidah al-Darar Yuzāl}

Sumber hukum dari kaidah ini diambil dari kalam Allah dan juga Hadits Nabi, sebagaimana terdapat dalam ayat-ayat al-Quran, diantaranya:

a. Al-Baqarah (2): 231, 233, dan 173

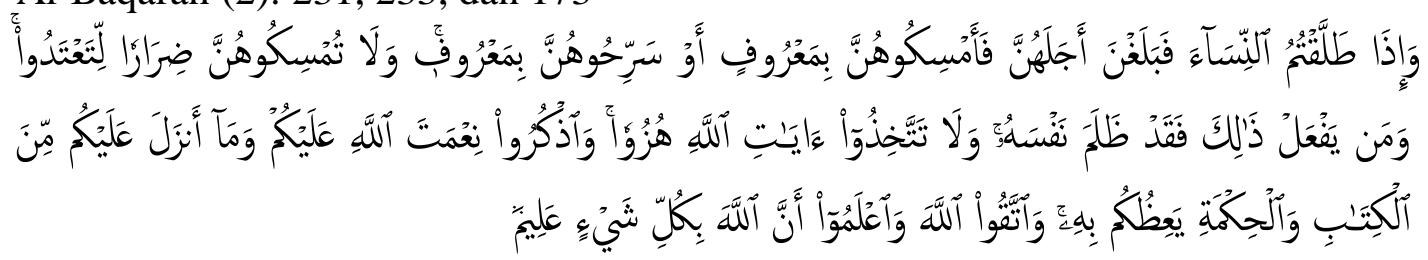

231. Apabila kamu mentalak isteri-isterimu, lalu mereka mendekati akhir iddahnya, maka rujukilah mereka dengan cara yang ma'ruf, atau ceraikanlah mereka dengan cara yang ma'ruf (pula). Janganlah kamu rujuki mereka untuk memberi kemudharatan, karena dengan demikian kamu menganiaya mereka. Barangsiapa berbuat demikian, maka sungguh ia telah berbuat zalim terhadap dirinya sendiri. Janganlah kamu jadikan hukum-hukum Allah permainan, dan ingatlah nikmat Allah padamu, dan apa yang telah diturunkan Allah kepadamu yaitu Al Kitab dan Al Hikmah (As Sunnah). Allah memberi pengajaran kepadamu dengan apa yang diturunkan-Nya itu. Dan bertakwalah kepada Allah serta ketahuilah bahwasanya Allah Maha Mengetahui segala sesuatu.

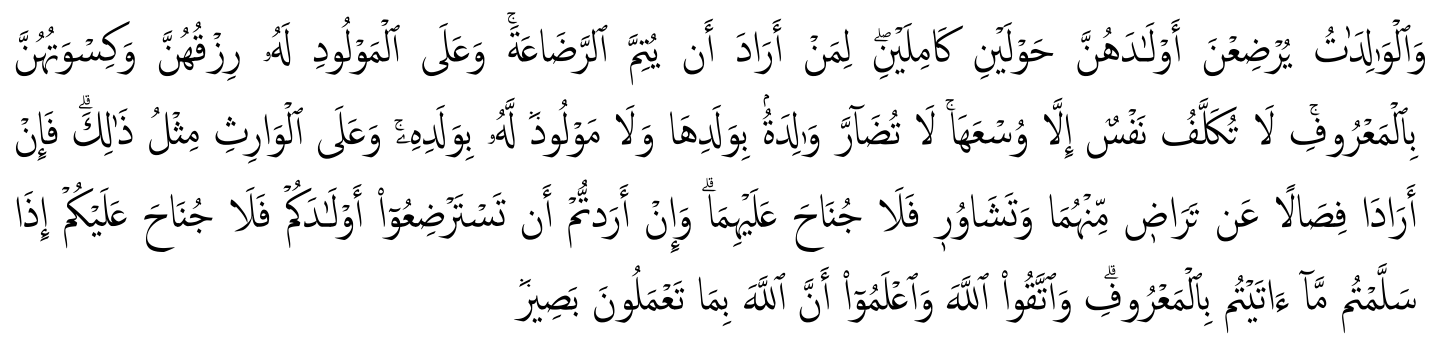

233. Para ibu hendaklah menyusukan anak-anaknya selama dua tahun penuh, yaitu bagi yang ingin menyempurnakan penyusuan. Dan kewajiban ayah memberi makan dan pakaian kepada para ibu dengan cara ma'ruf. Seseorang tidak dibebani melainkan menurut kadar kesanggupannya. Janganlah seorang ibu menderita kesengsaraan karena anaknya dan seorang ayah karena anaknya, dan warispun berkewajiban demikian. Apabila keduanya ingin menyapih (sebelum dua tahun) dengan kerelaan keduanya dan permusyawaratan, maka tidak ada dosa atas keduanya. Dan jika kamu ingin anakmu disusukan oleh orang lain, maka tidak ada dosa bagimu apabila kamu memberikan pembayaran menurut yang patut. Bertakwalah kamu kepada Allah dan ketahuilah bahwa Allah Maha Melihat apa yang kamu kerjakan.

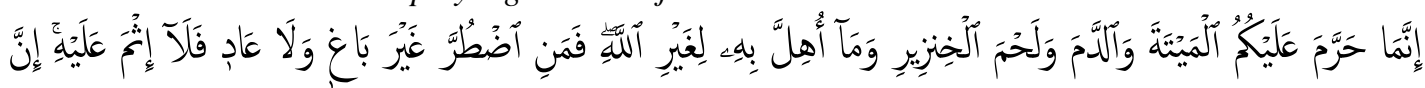

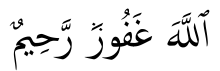


173. "Sesungguhnya Allah hanya mengharamkan bagimu bangkai, darah, daging babi, dan binatang yang (ketika disembelih) disebut (nama) selain Allah. Tetapi barangsiapa dalam keadaan terpaksa (memakannya) sedang dia tidak menginginkannya dan tidak (pula) melampaui batas, maka tidak ada dosa baginya. Sesungguhnya Allah Maha Pengampun lagi Maha Penyayang”

b. At-Thalaq (65): 6

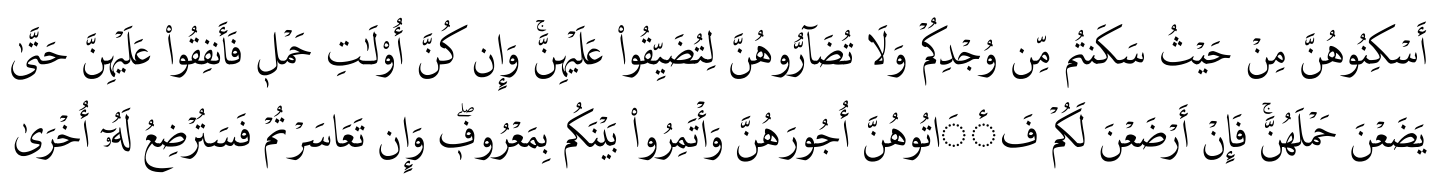

6. Tempatkanlah mereka (para isteri) di mana kamu bertempat tinggal menurut kemampuanmu dan janganlah kamu menyusahkan mereka untuk menyempitkan (hati) mereka. Dan jika mereka (isteriisteri yang sudah ditalaq) itu sedang hamil, maka berikanlah kepada mereka nafkahnya hingga mereka bersalin, kemudian jika mereka menyusukan (anak-anak)mu untukmu maka berikanlah kepada mereka upahnya, dan musyawarahkanlah di antara kamu (segala sesuatu) dengan baik; dan jika kamu menemui kesulitan maka perempuan lain boleh menyusukan (anak itu) untuknya.

c. al-Maidah (5): 105

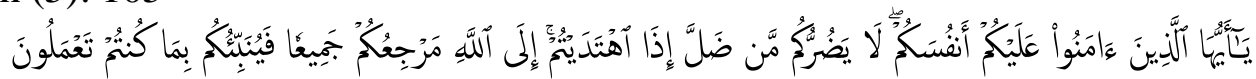

105. Hai orang-orang yang beriman, jagalah dirimu; tiadalah orang yang sesat itu akan memberi mudharat kepadamu apabila kamu telah mendapat petunjuk. Hanya kepada Allah kamu kembali semuanya, maka Dia akan menerangkan kepadamu apa yang telah kamu kerjakan.

d. Al-An'am (6): 119

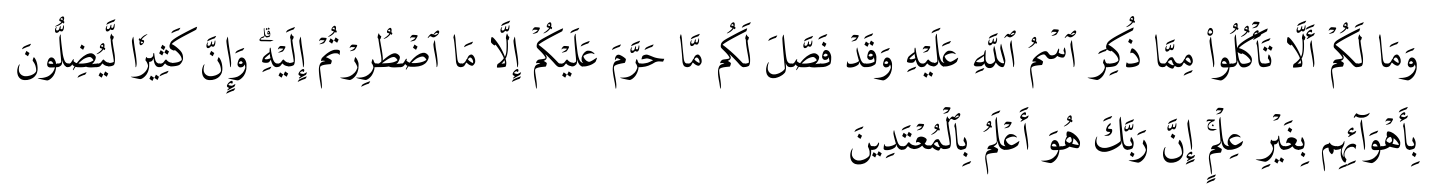

119. Mengapa kamu tidak mau memakan (binatang-binatang yang halal) yang disebut nama Allah ketika menyembelihnya, padahal sesungguhnya Allah telah menjelaskan kepada kamu apa yang diharamkan-Nya atasmu, kecuali apa yang terpaksa kamu memakannya. Dan sesungguhnya kebanyakan (dari manusia) benar benar hendak menyesatkan (orang lain) dengan hawa nafsu mereka tanpa pengetahuan. Sesungguhnya Tuhanmu, Dialah yang lebih mengetahui orang-orang yang melampaui batas.

Dan juga sumber dari kaidah ini berasal dari beberapa hadis Nabi dan menurut beberapa perawi dikatakan, yaitu:

a. Imam Malik

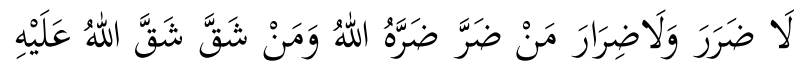

"Dilarang memudharatkan dan dimudharatkan. Barang siapa yang berbuat mudharat maka Allah akan memudharatkannya, dan barang siapa yang menyulitkan orang lain maka Allah akan menyulitkannya.",

b. Imam al-Bukhari

\footnotetext{
${ }^{8}$ Rachmat Syafe'I, Ilmu Ushul Fiqih (Bandung: Pustaka Setia, 2018), 289.
} 


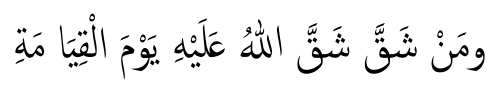

"Dan bagi siapa yang memberikan kesulitan pada orang lain, maka Allah akan memberikan kesulitan juga padanya kelak pada hari kiamat."9

c. Imam Muslim

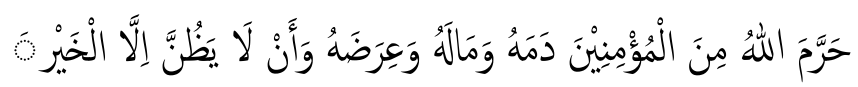

"Telah mengharamkan Allah terhadap orang mukmin, yaitu darahnya, hartanya, kehormatannya, dan tidak boleh melakukan persangkaan kecuali persangkaan yang baik. "10

d. Imam Muslim

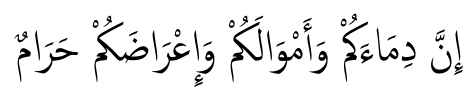

"Bahwasanya darah kalian seтua dan harta kalian sетиa, serta kehormatan kalian semua ialah haram diantara kalian semua."

\section{Cabang-cabang Kaidah}

Beberapa kaidah yang termasuk cabang dari kaidah $a l$-Darar $Y u z a>l$, diantaranya: ${ }^{12}$

1) الضَّروْْرَةُ تُنْيْحُ الَْحْظُوْرَاتِ

"Kemudharatan-kemudharatan itu membolehkan larangan-larangan"

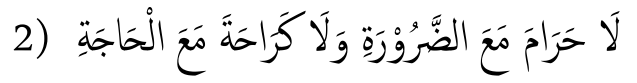

"Tidak dihukumi haram apabila dihadapkan dengan darurat dan tidak pula dihukumi makruh apabla dihadapkan dengan hajat"

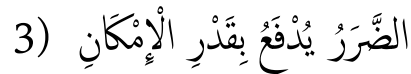

"Kemudharatan harus dicegah sedapat mungkin"

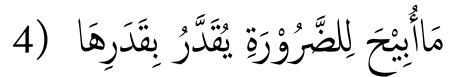

"Sesuatu yang dibolehkan karena darurat, diukur sesuai dengan kadar kemudharatannya"

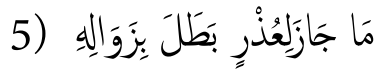

"Sesuatu yang boleh karena uzur menjadi tidak boleh lantaran telah hilangnya uzur"

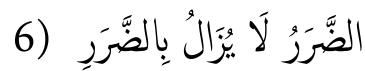

"Suatu hal yang mudharat itu tiada kebolehan untuk diganti dengan memberikan mudharat yang lain"

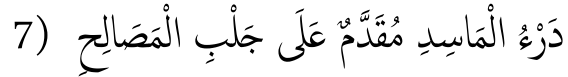

"Menolak kerusakan harus didahulukan dari pada mendatangkan kemaslahatan"

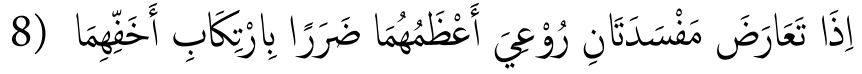

\footnotetext{
9 Toha Andiko, Ilmu Qawa'id Fiqhiyyah: Panduan Praktis Dalam Merespon Problematika Hukum Islam Kontemporer (Yogyakarta: Teras, 2011), 17.

${ }^{10}$ A. Djazuli, Kaidah-Kaidah Fikih: Kaidah-kaidah Hukum Islam dalam Menyelesaikan Masalah-Masalah yang Praktis (Jakarta: Kencana, 2006), 70.

${ }^{11}$ Ibid., 70.

${ }^{12}$ Duski Ibrahim, Al-Qawa Id Al-Fiqhiyah (Kaidah-Kaidah Fiqih) (Palembang: Amanah, 2019), 89.
} 
"Jika terdapat dua kerusakan yang bertentangan maka diharuskan memelihara yang paling banyak mudaratnya dan mengambil yang lebih sedikit mudaratnya”

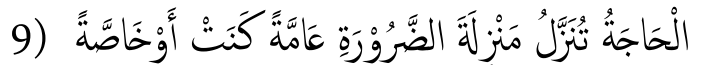

"Suatu hajat diletakkan pada posisi darurat, baik hajat itu sifatnya umum maupun khusus"

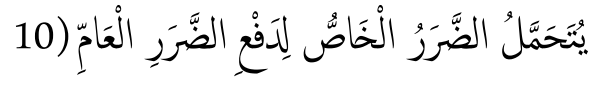

"Suatu kemudaratan yang khusus harus ditanggung demi menghindari kemudaratan yang umum"

\section{Hakikat Transfusi Darah}

\section{Definisi Transfusi Darah}

Kata transfusi darah merupakan terjemahan dari "blood transfution" yaitu dari bahasa Inggris. Kemudian seorang dokter dari Arab menerjemahkan dengan "pemindahan darah yang disebabkan suatu kebutuhan medis". Kemudian diartikan dengan istilah "memindahkan lalu menuangkan darah" oleh Dr. Ahmad Sofyan. Lalu kemudian dirumuskannya definisi transfusi darah dengan makna, "memindahkan-menuangkan darah artinya memasukkan darahnya melalui pembuluh darah kepada orang lain yang dibantunya". 13

Adapun definisi transfusi darah menurut Syekh Al-Husain Muhammad Makhluf mengatakan yaitu, ${ }^{14}$

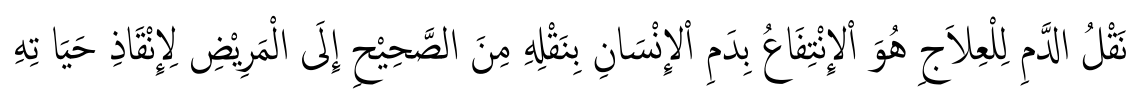

Transfusi darah merupakan mengambil manfaat dari darah seseorang, yaitu yang sehat tubuhnya lalu dipindahkannya ke tubuh orang yang sakit karena untuk mempertahankan hidup.

Oleh karena itu, dikatakan bahwa transfusi darah merupakan cara pemindahan darah. Salah satu unsur darah yang didonorkan oleh seseorang (pendonor) untuk orang lain (resipien), hal ini dilakukan sebagai bentuk upaya menyelamatkan nyawa dan juga untuk meningkatkan kesehatan.

Darah merupakan cairan tubuh yang sangat vital bagi kehidupan manusia, yang bersikulasi dalam jantung dan pembuluh darah. Darah membawa oksigen dan nutrisi bagi seluruh sel dalam tubuh serta mengangkat produk-produk hasil metabolisme sel. Darah berada di suatu pembuluh darah arteri maupun vena, dan merupakan sebagian dari sistem organ tubuh manusia yang berperan penting bagi kelangsungan hidup manusia. Volume darah total dalam tubuh manusia dewasa adalah berkisar 3,6 liter (wanita) dan 4,5 liter (pria). Di dalam darah mengandung sel-sel darah serta cairan yang di sebut plasma darah yang berisi berbagai zat nutrisi maupun substansi lainnya. Sekitar 55\% darah merupakan komponen cairan atau plasma, sisanya yang 45\% adalah komponen sel-sel darah. Komponen sel-sel darah yang paling banyak adalah sel darah merah atau eritrosit yaitu sejumlah $41 \%$. Rasio volume sel-sel darah terhadap volume darah total disebut hematocrit (Hct). Lebih dari 99\% hematocrit dibentuk oleh eritrosit. Komponen darah manusia secara rinci terdiri atas: ${ }^{15}$

\footnotetext{
${ }^{13}$ Sudarto, Masailul Fiqhiyah al-Haditsah (Yogyakarta: Qiara Media, 2020), 152.

${ }^{14}$ Ibid., 152.

${ }^{15}$ Novi Khila Firani, Mengenali Sel-sel Darah dan Kelainan Darah (Malang: UB Press, 2018), 1-4.
} 
a. Sel-sel darah meliputi

1) Eritrosit (sel darah merah), berfungsi dalam transportasi oksigen dan karbon dioksida.

2) Leukosit (sel darah putih), berperan dalam imunitas atau pertahanan tubuh terhadap benda asing maupun mikroorganisme. Leukosit terdiri dari Neutrofil, Eosinofil, Basofil, Limfosit, Monosit.

3) Trombosit (keping darah), berfungsi dalam proses pembekuan darah, yang berperan penting untuk sistem hemostasis dalam tubuh.

b. Plasma darah, merupakan komponen cairan yang mengandung berbagai nutrisi maupun substansi penting lainya yang diperlukan oleh tubuh manusia, antara lain protein albumin, globulin, faktor-faktor pembekuan darah, dan berbagai macam elektrolit natrium $\left(\mathrm{Na}^{+}\right)$, kalium $\left(\mathrm{K}^{+}\right)$, klorida $\left(\mathrm{C}^{+}\right)$, magnesium $\left(\mathrm{Mg}^{2+}\right)$, hormon, dan sebagainya.

Berdasarkan terapi komponen darah, seorang pasien berdasarkan penyakitnya diberikan hanya komponen darah yang diperlukan tubuhnya saja. Ada yang hanya membutuhkan sel darah merah, yang lainnya hanya membutuhkan platelet-Nya saja. Namun tidak jarang yang membutuhkan transfusi darah secara utuh (whole blood). ${ }^{16}$

\section{Indikasi-Indikasi Untuk Transfusi Darah}

Beberapa indikasi perlunya seseorang melakukan transfusi darah pada orang lain ialah disebabkan karena: a) hilangnya darah, serta b) kurangnya komponen-komponen penting pada darah. $^{17}$

a. Kehilangan darah

Disebabkan hilangnya darah bisa berakibat pada kurangnya bobot darah seseorang yang mengaliri seluruh tubuh. Dalam hal ini karena sebab faktor, diantaranya:

1) Pendarahan yang disebabkan luka, atau juga sebab terjadi koreng, melahirkan, atau peradangan usus.

2) Sebab luka seperti, luka karena terbakar, atau terjadi pembengkakan karena kecelakaan.

3) Sebab melakukan operasi misal, pada jantung, dan jenis operasi lainnya.

4) Tiada kecocokan darah diantara ibu dan anaknya. Pada kasus seperti ini perlu dilakukan transfusi untuk menukarkan dalam upaya penyelamatan nyawa anak.

5) Terjadi anemia kronis atau akut, atau terjadi ketidaknormalan pada sistem darah beku yaitu, hemophilia.

b. Kekurangan komponen-komponen penting pada darah

Terkadang pasien tidak datang untuk melakukan transfusi darah untuk semua komponen darah namun hanya butuh untuk sebagian komponen saja, sesuai dengan tingkat kebutuhannya, hal ini bisa terjadi pada kasus;

1) Anemia, yaitu pasien mengalami kurangnya sel darah merah. Jadi hanya butuh melakukan transfusi darah merah saja.

2) Hemofilia, yaitu disebabkan karena kerusakan pada sistem pembekuan darah, yang mengakibatkan pada anemia dan juga kekurangan darah yang berisiko ketika terjadi luka apa pun kecilnya, disebabkan karena proses membukanya darah yang sangat

\footnotetext{
16 Johanes F Koraag, Berbagi Nyawa: Hidup Bahagia dengan Berdonor Darah (Yogyakarta: Pustaka Marwa, 2010), 83 .

17 Abul Fadl Mohsin Ebrahim, Fikih Kesehatan: Kloning, Eutanasia, Transfusi Darah, Transplantasi Organ, dan Eksperimen pada Hewan (Jakarta: Serambi Ilmu Semesta, 2007), 58.
} 
lamban. Oleh karena itu, untuk mencegah terjadinya pendarahan maka pasien wajib transfusi untuk plasma darahnya atau pasien tersebut boleh dilakukan injeksi dengan menggunakan AHF (antibaemophilic faktor).

Perlu diketahui bahwa karena plasma sama sekali tidak memiliki sel darah, maka seorang pasien yang menderita pendarahan serius memerlukan setidaknya satu pint $(0,568$ liter) darah untuk setiap pint plasma yang ditransfusikan.

\section{Pelaksanaan Transfusi Darah ${ }^{18}$}

\section{a. Sebelum dilakukan Transfusi Darah}

Jadi sebelum dilakukan pemindahan (transfusi) darah pada pasien perlu dilakukan pengambilan sampel darah terlebih dahulu sebagai upaya pengecekan pada jenis darahnya. Golongan atau jenis darah yaitu ABO diantaranya, A, B, AB, dan juga O. Sedangkan menurut rhesus atau Rh terbagi 2 yakni, Rh yang positif dan juga negatif. Kemudian akan dilakukan crossmatch yaitu jika jenis darahnya sesuai maka dilanjut untuk diperiksa lagi dalam hal ini mencari kecocokan antara jenis darah si pendonor dengan jenis darah si resipien sebagai penerima donor. Ketika dilakukannya crossmatch, juga akan diperhatikan adanya antibodi yang dapat menyebabkan penyerangan pada sel darah si pendonor dan juga dapat mengancam tubuh si resipien.

\section{b. Langkah-langkah Proses Dilakukannya Transfusi Darah}

Pada umumnya pemindahan darah bisa dilangsungkan selama kurang lebih 4 jam, hal ini bergantung pada berapa banyak menransfusikannya. Sebelum ditusukkannya jarum di daerah lengannya pada pembuluh darahnya, maka dokter akan meminta pasien untuk berbaring di atas tempat tidur atau juga bersandar di atas kursi. Lalu ketika jarum dimasukkan ke pembuluh darah maka dokter akan menghubungkan pada selang yang tipis atau kateter yang disambungkan dengan kantong darahnya. Dengan kantong darah itu lalu dialirkannya darah dengan memakai kateter mengarah ke pembuluh darahnya.

Dan kondisi pasien akan terus dilakukan pemantauan selama selang waktu 15 menit, hal ini dilakukan untuk mengetahui dengan pasti bahwa tidak akan terjadi alergi dari reaksi pasien. Namun jika terdapat tanda-tanda akan terjadinya alergi dari reaksi yang terjadi maka harus cepat diberhentikan. Namun jika selama 1 jam dijalankan dan tidak ditemukan terjadinya alergi dari reaksi yang didapatkan maka perawat maupun dokter dapat melakukan langkah selanjutnya, yaitu pemindahan darah.

\section{c. Sesudah Dilakukan Pemindahan Darah}

Ketika selang dilepaskan oleh perawat atau dokter dari pembuluh darahnya. Maka dokter maupun perawat akan terus memantau pada kondisi vital pasien, baik denyut pada jantung pasien, tekanan darahnya, sampai pada suhu badan pasien tersebut.

\section{d. Risiko Pemindahan (Transfusi) Darah}

Adapun efek negatif yang mungkin terjadi setelah dilakukannya pemindahan darah maupun menjelang waktu sesudahnya meski hal ini jarang terjadi, yaitu: ${ }^{19}$

1) Demam. Hal ini bisa terjadi ketika transfusi darah. Dalam hal ini adalah suatu reaksi yang terjadi pada tubuh resipien ketika sel darah putih mulai menyebar ke dalam tubuh.

\footnotetext{
${ }^{18}$ Tjin Willy, “Transfusi Darah, Ini Yang Harus Anda Ketahui”, Alodokter, https://www.alodokter.com/transfusi-darahini-yang-harus-anda-ketahui, diakses pada 17 Mei 2018, 1.

${ }^{19}$ Ibid., 1.
} 
Untuk masalah ini dapat diobati dengan meminum obat untuk meredakan demamnya atau batal melakukan transfusi darah.

2) Terjadinya alergi, Biasanya ditandai dengan perasaan ketidaknyamanan, terasa sakit di bagian punggung maupun dada, kesulitan nafas, memerah pada bagian kulit, mual, menurunnya tekanan darah, detak jantung sangat cepat, serta menggigil.

3) Zat besi yang berlebih. Hal ini bisa disebabkan karena banyaknya jumlah darah yang ditransfusikan seperti yang dialami penderita thalassemia. Dikarenakan keseringan melakukan pemakaian donor darah hingga terjadi zat besi yang berlebih. Sehingga berakibat pada rusaknya organ tubuh resipien seperti hati, jantung, dan lainnya.

4) Berakibat cedera pada paru-paru si pendonor, pendonoran darah juga dapat berakibat pada rusaknya paru-paru. Meskipun peristiwa tersebut jarang ditemukan namun umumnya terjadi 6 jam sesudahnya. Pada beberapa kasus, penderita pada kasus ini bisa sembuh tapi sekitar 5-25\% pasien yang menderita penyakit ini juga bisa kehilangan nyawanya.

5) Infeksi. Penyakit ini bisa ditularkan dari darah pendonor, contoh halnya Human immunodeficiency Virus (HIV), Hepatitis B, C, atau juga D. Akan tetapi pada masa sekarang sangat jarang terjadi, dikarenakan prosedur donor dilakukan dengan sangat baik yakni sebelum dilakukan transfusi darah sudah melalui tahapan pemeriksaan terlebih dahulu untuk melihat tidak adanya penyakit tersebut yang dapat menular dari darah.

\section{Analisa Hukum Transfusi Darah Berdasarkan Kaidah al-Darar Yuzāl}

Berdasarkan fakta bahwa memang tidak terdapat sumber-sumber orisinal Islam tentang larangan praktik transfusi darah. Namun keterangan-keterangan yang ditemukan hanya menyebutkan bahwa darah adalah benda najis dan tidak boleh dikonsumsinya. Akan tetapi ketidakbolehan ini tidaklah berlaku ketika mendapati kebutuhan yang mendesak, yaitu ketika transfusi darah menjadi satu-satunya jalan untuk menyelamatkan nyawa seseorang. Hal ini didasarkan pada kaidah fiqhiyah asasiyah yakni kaidah yang ke-4 (empat) yaitu:

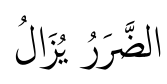

Artinya: "bahaya itu harus dihilangkan (dicegah)"

Dalam kaidah ini mengisyaratkan bahwa terdapat kelonggaran hukum yaitu misal dibolehkannya mengonsumsi makanan yang haram pada saat terdesak/terpaksa. Hal ini sejalan dengan kaidah

$$
\text { لَا حَرَامَ مَعَ الضَّروْْرَة وَلَا كَراحَةَ مَنَ الْحَاجَةِ }
$$

Artinya: "tiada yang dapat menghukum haram kalau ada kemudaratan dan juga tiada yang dapat menghukum makruh kalau ada kebutuhan". ${ }^{20}$

Adapun dasar hukum dari persoalan adanya pengecualian hukum terhadap keadaan terpaksa ini, ialah apa yang diceritakan di dalam kitab Allah SWT sesudah cerita tentang berbagai makanan yang diharamkan, dimana Allah mengecualikan keadaan terpaksa dan lapar. Pengecualian ini terdapat pada empat tempat yang sudah disebutkan di awal yaitu di

\footnotetext{
${ }^{20}$ Duski Ibrahim, Al-Qawa Id Al-Fiqhiyah..., 89.
} 
dalam al-Quran; dua tempat dari surat-surat Makkiyah, yaitu al-An'an dan an-Nahl dan dua lainnya dari surat-surat Madaniyah, yaitu al-Baqarah dan al-Maidah. ${ }^{21}$

Dalam hal ini ketika seseorang berada di posisi dharurat yakni sangat memerlukan transfusi darah meski darah hukumnya haram maka menjadi halal untuk digunakan. Hal ini juga selaras dengan kaidah,

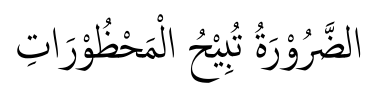

"kemudharatan-kemudharatan itu membolehkan larangan-larangan". 22

Keadaan dharurat menjadikan kebolehan untuk mengerjakan suatu hal yang bersifat larangan terkecuali pada kondisi seorang donor darah tersebut sudah memenuhi persyaratan keamanan dari prosedur yang ditentukan.

Ketika si pendonor menyetujui untuk mendonorkannya maka hak atas darahnya berpindah kepada resipien. Akan tetapi dalam ranah hukum Islam dilarang seseorang mendonorkan darahnya apabila berakibat buruk pada keselamatan dan kesehatannya. Dalam hal ini berdasarkan kaidah

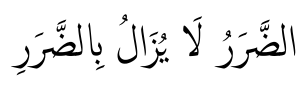

"kemudaratan itu tiada kebolehan untuk diganti pada mudarat lainnya". 23

Penjelasan dari kaidah diatas ialah suatu hal yang bersifat mudarat tidak dibolehkan diganti dengan mudarat pula pada tingkat kondisi yang sama. Meski dalam hal ini seseorang sangat membutuhkan darah akan tetapi apabila mendonorkan akan berdampak buruk bagi pendonor tersebut maka haram hukumnya dilakukan transfusi darah. Maka dari itu, dalam melakukan transfusi darah harus memenuhi persyaratan yang ada, diantaranya: ${ }^{24}$

1) mendonorkan darah secara ikhlas, hal ini dilakukan dengan niatan untuk membantu orang yang sangat memerlukan donor darah. Hal ini berdasarkan kaidah

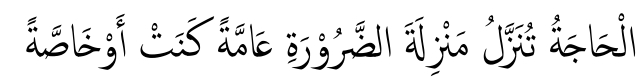

Hajat itu menempati pada posisi darurat, baik hajat yang sifatnya khusus ataupun umum. $^{25}$

2) Tidak terdapat bahaya yang dapat mengancam jiwa atau kesehatan donor akibat dari transfusi tersebut. Dalam hal ini ditetapkan oleh seorang yang dokter yang benar-benar kompeten dan terpercaya. Hal ini berdasarkan kaidah

\footnotetext{
${ }^{21}$ Yusuf Al-Qardlawy, Keluasan Dan Keluwesan Hukum Islam (Semarang: Toha Putra Group, 1993), 49.

${ }^{22}$ A. Djazuli, Kaidah-Kaidah Fikih:..., 72.

${ }^{23}$ Umar faruq, Al-faraidul bahiyyah: fii al-qawaid al-fiqhiyyah (Surabaya: Mahkota), 66.

${ }^{24}$ Abul Fadl Mohsin Ebrahim, Fikih Kesehatan..., 64.

${ }^{25}$ Wahyu Setiawan, Qawaidh Fiqhiyyah (Jakarta: Amzah, 2019), 21.
} 


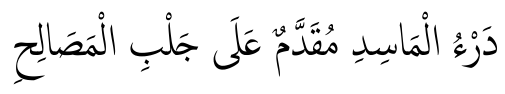

Artinya: "mencegah bahaya lebih diutamakan dibanding mendatangkan kemaslahatan. ,26

3) Harus benar-benar pasti sudah tiada cara lainnya dalam upaya penyelamatan hidup pasien (resipien) dengan cara melakukan transfusi darah. Dalam hal ini berada di posisi keadaan yang sangat terpaksa (darurat) dan sangat membutuhkan donor darah tersebut. Maka hal itu harus segera dilakukan transfusi sebagai bentuk untuk menyelamatkan nyawa resipien.

Islam mengajarkan tentang dasar-dasar menghilangkan kesukaran atau kesusahan (musyaqqah), jaminan kemaslahatan untuk setiap orang pada umumnya, serta menciptakan sifat yang adil secara merata. Adapun kemaslahatan mesti diwujudkan oleh Allah SWT, yaitu pada 5 hal yang kaitannya dengan kebutuhan dasar kemanusiaan, diantaranya: Hifź al-Din, Hifz al-Nafs, Hifz al-'Aql, Hifzal-Nasl, Hifz al-Māl. Dari 5 hal tersebut mengacu pada pemeliharaan yang dikatakan kemashlahatan. ${ }^{27}$ Jadi transfusi darah merupakan salah satu bentuk pemeliharaan jiwa kepada resipien yang sangat memerlukannya. Namun apabila kemaslahatan itu tidak dipenuhi yakni donor darah tidak dilakukan maka akan timbul suatu akibat yang sangat fatal (kemudaratan) kepada seseorang tersebut.

4) Sedangkan tingkat keberhasilan melalui cara pengobatan ini diperkirakan tinggi. Dalam hal ini semua sudah dilakukan tahapan-tahapan pemeriksaan yang teliti terhadap kesehatan kedua-duanya dan didampingi oleh tenaga medis yang berkompeten dibidangnya maka sudah barang tentu keberhasilan akan dicapai.

\section{Penutup}

Sebagaimana pernyataan diatas maka dapat diberikan kesimpulan yaitu hukum transfusi darah adalah boleh. Meskipun tidak terdapat sumber-sumber orisinal Islam tentang larangan praktik transfusi darah. Namun keterangan-keterangan yang ditemukan hanya menyebutkan bahwa darah adalah benda najis dan tidak boleh dikonsumsinya. Akan tetapi ketidakbolehan ini tidaklah berlaku ketika mendapati kebutuhan yang mendesak, yaitu ketika transfusi darah menjadi satu-satunya jalan untuk menyelamatkan nyawa seseorang. Hal ini selaras dengan kaidah fiqhiyah asasiyah yakni kaidah yang ke-4 (empat) yaitu: al-Ḍarar Yuzāal (الضَّرَرُ يُزََالُ (bahaya itu harus dihilangkan (dicegah)).

\footnotetext{
${ }^{26}$ A. Djazuli, Kaidah-Kaidah Fikih..., 29.

${ }^{27}$ A. Malthuf Siroj, Paradigma Ushul Fiqh (Yogyakarta: Pustaka Ilmu, 2013), 2.
} 
Melihat banyaknya pasien yang membutuhkan darah sedangkan persediaan darah sangat terbatas, maka sebagai insan sosial sangat dibutuhkan kesadarannya untuk mendonorkan darahnya. Karena mendonorkan darah termasuk amal kemanusiaan yang sangat besar serta sosial yang tinggi, maka sebaiknya harapan penulis mari bersama-sama memberikan dorongan kepada lembaga atau organisasi agar aktif menyumbangkan darahnya. Penulis juga menghimbau agar para lembaga swadaya masyarakat tidak hanya perhatian terhadap persoalan-persoalan pemberdayaan di masyarakat, akan tetapi juga penulis sarankan agar perhatian terhadap penderita penyakit atau kecelakaan lebih-lebih terhadap orang yang sangat memerlukan donor darah.

\section{Daftar Rujukan}

Abd. Madjid, Ahmad. Ushul Figh. Pasuruan: Garoeda Buana Indah, 1991.

Fathurrahman, Azhari. Qawā'id fiqhiyyah muamalah. Banjarmasin: LPKU, 2015.

Toha, Andiko. Ilmu Qawā'id fiqhiyyah: panduan praktis dalam merespon problematika hukum Islam kontemprorer. Yogyakarta: Teras, 2011.

Jhon W, Creswell. Qualitative inquiry and research design: chosing among five approach. Amerika: Sage, 2013.

Djazuli, A. kaidah-kaidah fikih: kiadah-kaidah hokum islam dalam menyelesaikan masalahmasalah yang praktis. Jakarta: kencana, 2006.

Ibrahim, Dasuki. al-Qawā'id al-fiqhiyah (kaidah-kaidah fiqh). Palembang: amanah, 2019.

Khila Firani, Novi. Mengenali Sel-sel Darah dan Kelainan Darah. Malang: UB Press, 2018.

F Koraag, Johanes. Berbagi Nyawa: Hidup Bahagia dengan Berdonor Darah. Yogyakarta: Pustaka Marwa, 2010.

Fadl Mohsin Ebrahim, Abul. Fikih Kesehatan: Kloning, Eutanasia, Transfusi Darah, Transplantasi Organ, dan Eksperimen pada Hewan. Jakarta: Serambi Ilmu Semesta, 2007.

Faruq, Umar. al-farāid al-bahiyyah: fī al-Qawā'id al-fiqhiyyah. Surabaya: Mahkota, tt.

Lexy J, moleong. Metodologi penelitian kualitatif. Bandung: PT remaja Rosdakarya, 2012.

Yusuf, al-Qardhawy. Keluasan dan keluwesan hukum Islam. Semarang: Toha putra Group, 1993.

Hendi, Suhendi. Fiqh muamalah. Jakarta: rajawali pers, 2014.

Eko, Sugiarto. Menyusun proposal penelitian kualitatif: skripsi dan tesis. Yogyakarta: suaka media, 2015.

Sudarto. Masailul Fiqhiyah al-Haditsah. Yogyakarta: Qiara Media, 2020. 
Rachmat, syafie. Ilmu ushul figh. Bandung: pustaka setia, 2018.

Sidikah Rachman, Fitriana. Nur Aditya, Robby. Question \& Answer: Donor Darah. Jakarta: Gramedia, 2013.

Setiawan, Wahyu. Qawaidh Fiqhiyyah. Jakarta: Amzah, 2019.

A. Malthuf. Siroj. Paradigma usul Fiqh. Yogyakarta: pustaka ilmu, 2013.

Utari, Reni. Risiko Komplikasi dan Efek Samping Transfusi Darah. Sehat KEMENKES RI. 09 September 2020.

Willy, Tin. Transfusi darah, ini yang harus diketahui. Alodokter. 17 mei 2018. 